\title{
Follicular assembly: mechanisms of action
}

\author{
Melissa E Pepling \\ Department of Biology, Syracuse University, 107 College Place, Syracuse, New York 13244, USA
}

Correspondence should be addressed to M E Pepling; Email: mepeplin@syr.edu

\begin{abstract}
The differentiation of primordial germ cells (PGCs) into functional oocytes is important for the continuation of species. In mammals, PGCs begin to differentiate into oocytes during embryonic development. Oocytes develop in clusters called germ line cysts. During fetal or neonatal development, germ cell cysts break apart into single oocytes that become surrounded by pregranulosa cells to form primordial follicles. During the process of cyst breakdown, a subset of cells in each cyst undergoes cell death with only one-third of the initial number of oocytes surviving to form primordial follicles. The mechanisms that control cyst breakdown, oocyte survival, and follicle assembly are currently under investigation. This review describes the mechanisms that have been implicated in the control of primordial follicle formation, which include programmed cell death regulation, growth factor and other signaling pathways, regulation by transcription factors and hormones, meiotic progression, and changes in cell adhesion. Elucidation of mechanisms leading to formation of the primordial follicle pool will help research efforts in ovarian biology and improve treatments of female infertility, premature ovarian failure, and reproductive cancers.

Reproduction (2012) 143 139-149
\end{abstract}

\section{Introduction}

Mammalian females have a reproductive lifespan that is determined by the time of birth. Establishment of the pool of primordial follicles, each consisting of an oocyte surrounded by a layer of somatic cells, is essential for fertility. This begins during embryonic development when germ cells arrive at the gonad and divide to form clusters of cells known as germ cell cysts. As the oocytes develop, these cysts begin to break apart, allowing each oocyte to become surrounded by a layer of somatic cells, forming primordial follicles. This process is referred to as primordial follicle formation or assembly. At the same time, there is a loss of approximately two-thirds of oocytes. Mechanisms regulating cyst breakdown, germ cell numbers, and primordial follicle assembly are currently under investigation. This review focuses on recent findings in the molecular regulation of cyst breakdown and primordial follicle formation.

\section{The process of follicular assembly}

In the mouse, primordial germ cells (PGCs) migrate from outside the embryo to the genital ridge at 10.5 days post coitus (dpc) and divide by mitosis until $13.5 \mathrm{dpc}$ (Monk \& McLaren 1981). The germ cells are called oogonia as they undergo these divisions and were described many years ago as developing in clusters or nests (Gondos 1973). However, more recently, these germ cell clusters were shown to exhibit the key characteristics of germ line cysts that have been described in Drosophila and other invertebrates (Pepling \& Spradling 1998). Germline cysts divide synchronously and are connected by intercellular bridges due to incomplete cytokinesis of oogonial division (de Cuevas et al. 1997). Thus, in this review, we will refer to the nests as germ cell cysts. The germ cell cysts are loosely surrounded by somatic cells and this grouping of germ cells and somatic cells is called the ovigerous cords (Byskov 1986). Examples of germ cell cysts within ovigerous cords are shown in Fig. 1. Germ cell cysts have been most well studied in Drosophila where the cells undergo four mitotic divisions to form 16 cell cysts (de Cuevas et al. 1997). One cell of the cyst becomes the oocyte while the remaining 15 become nurse cells and supply nutrients to the oocyte. In the mouse, the number of divisions is variable and the function of cysts is unclear (Pepling \& Spradling 1998). Oogonia become oocytes when they enter meiosis beginning at $13.5 \mathrm{dpc}$. Oocytes progress through the stages of meiotic prophase I (leptotene, zygotene, and pachytene) and arrest in the diplotene stage beginning at $17.5 \mathrm{dpc}$ with most cells reaching diplotene by postnatal day 5 (PND5) (Borum 1961).

Oocytes separate by a process called cyst breakdown and become enclosed in primordial follicles consisting of one oocyte and several granulosa cells (Fig. 2; Pepling \& Spradling 2001). During cyst breakdown, some cells in each cyst die by programmed cell death with only one-third of the total surviving. In one model, one cell of 

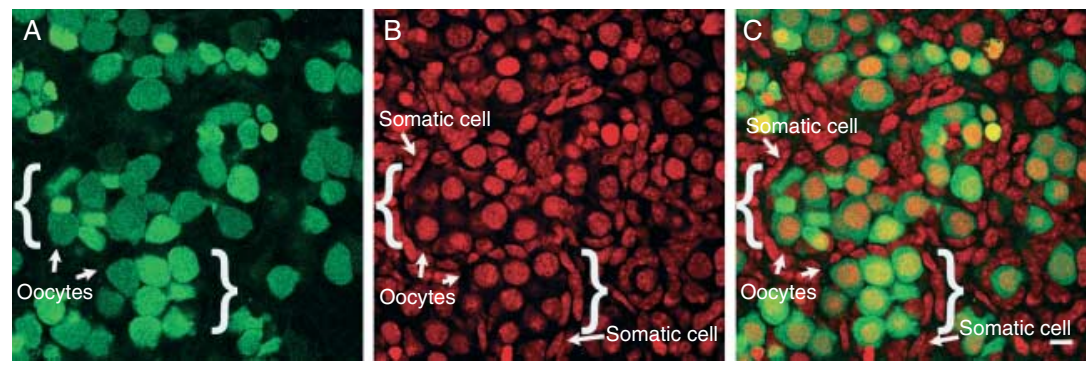

Figure 1 Germ cell cysts within ovigerous cords in a PND1 Oct4-GFP mouse ovary confocal section. (A) Oocytes expressing GFP (green), (B) stained for DNA (propidium iodide, red) and (C) overlay. Ovigerous cords consist of germ cell cysts and surrounding somatic cells. Two cysts within ovigerous cords are indicated by brackets. Scale bar $=10 \mu \mathrm{m}$. PND1, postnatal day 1; GFP, green fluorescent protein; Oct4 (POU5F1), POU class 5 homeobox 1.

a cyst dies and the large cyst breaks into two smaller cysts. This is repeated until a few individual oocytes remain. The cyst cells may also support oocytes and eventually die analogous to nurse cells in Drosophila. Oocytes in primordial follicles represent the entire pool available during a female's reproductive life. After sexual maturity, cohorts of follicles are recruited to grow by a process called follicle activation (McGee \& Hsueh 2000). Some follicles that are activated eventually die by a process called follicular atresia while oocytes in surviving follicles undergo ovulation.

Regional differences in germ cell cyst breakdown, oocyte loss, and follicle formation have been observed. Oocyte loss and cyst breakdown begin after birth in the cortical region of the ovary, but in the medullary region, these processes begin as early as $17.5 \mathrm{dpc}$ (Pepling et al. 2010). This is similar to other studies on the mouse and also on humans where oocyte loss has been observed during fetal development (De Pol et al. 1997, De Felici et al. 1999, McClellan et al. 2003, Ghafari et al. 2007). In the rat, follicles are first observed in the core of the ovary and formation gradually shifts toward the surface (Rajah et al. 1992). The follicles closer to the medullary region are also the follicles that begin to develop first (Hirshfield \& DeSanti 1995). In addition, oocytes located in the inner cortex and medullary region enter meiosis and start to grow first (Peters 1969, Nandedkar et al. 2007). This regional pattern is set up between 13.5 and $16.5 \mathrm{dpc}$ in the mouse as the germ cells are entering meiosis (Byskov et al. 1997).

\section{Interactions between germ cells and somatic cells}

As the oogonia divide and form germ cell cysts, the cell clusters become enclosed in ovigerous cords consisting of germ cell cysts and somatic pregranulosa cells arranged in irregular branches (Byskov 1986). The cords are surrounded by a basal lamina (Mazaud et al. 2005) and are well defined in some species but not as prominent in the mouse (Byskov 1986). The ovigerous cords become fragmented as the oocytes separate and individual oocytes become enclosed in a layer of granulosa cells. The basal lamina of the ovigerous cords is remodeled as the cords fragment and follicles are formed (Mazaud et al. 2005). The process of follicle formation likely involves communication between oocytes and granulosa cells (potential signals are discussed below). In addition, processes extending from somatic cells have been observed between oocytes suggesting that somatic cells may physically separate oocytes (Pepling \& Spradling 2001).

\section{Programmed cell death}

In the mouse, cyst breakdown and oocyte loss occur concurrently, suggesting they are linked. Mechanisms governing oocyte death during cyst breakdown are not well understood but are thought to involve apoptosismediated programmed cell death. Table 1 shows programmed cell death regulators with putative roles in primordial follicle assembly. B-cell lymphoma/ leukemia-2 (BCL2) family members regulate apoptosis and can be divided into two groups, pro-apoptotic (such as BAX, BAK, and BAD) and anti-apoptotic (such as BCL2, BCLX, and MCL1) (Kim \& Tilly 2004). In the ovary, several BCL2 family members have been implicated in the regulation of oocyte survival. Adult female $B C / 2$ knockout mice have fewer oocytes than wild-type mice, suggesting that BCL2 is important for oocyte survival though it is not known when the oocytes are lost in the knockout mice (Ratts et al. 1995). Overexpression of BCL2 in germ cells results in ovaries with more oocytes at PND8; however, by PND60, transgenic ovaries have the same number of oocytes as wildtype ovaries, suggesting that there is a mechanism to detect excess oocytes (Flaws et al. 2001). There is also evidence that the pro-apoptotic family member BAX is involved in regulating oocyte numbers (Perez et al. 1999). Neonatal Bax mutant ovaries have more oocytes than wild-type mice and more oocytes still in germ cell cysts linking

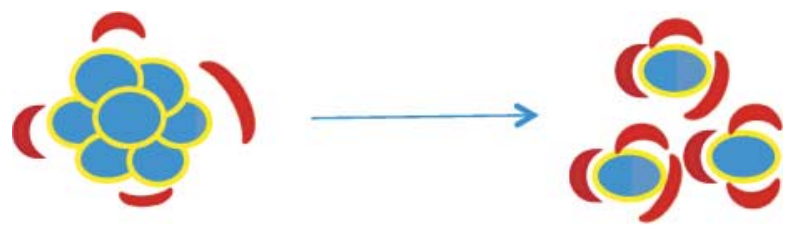

Figure 2 Diagram of cyst breakdown and primordial follicle assembly. Blue ovals are oocyte nuclei. Yellow indicates oocyte cytoplasm. Red moons are granulosa cells. As cysts break apart, some oocytes are lost by programmed cell death. Granulosa cells surround each surviving oocyte forming primordial follicles. 
Table 1 Programmed cell death regulators that affect oocyte survival or cyst breakdown during follicle assembly.

\begin{tabular}{|c|c|c|c|}
\hline Genes & Protein/function & Evidence for role in follicle assembly & References \\
\hline $\operatorname{Atg} 7$ & Involved in autophagy & Loss of germ cells by PND1 & Gawriluk et al. (2011) \\
\hline Bax & $\mathrm{Bcl} 2$ family of apoptosis regulators & $\begin{array}{l}\text { Increased oocyte survival, reduced cyst breakdown } \\
\text { and follicle formation }\end{array}$ & $\begin{array}{l}\text { Perez et al. (1999) and } \\
\text { Greenfeld et al. (2007) }\end{array}$ \\
\hline$B C l 2$ & $\mathrm{Bcl} 2$ family of apoptosis regulators & $\begin{array}{l}\text { Mutation results in reduced oocyte numbers, over- } \\
\text { expression results in increased oocyte numbers }\end{array}$ & $\begin{array}{l}\text { Ratts et al. (1995) and } \\
\text { Flaws et al. (2001) }\end{array}$ \\
\hline Becn1 & Involved in autophagy & Reduced oocyte numbers at PND1 & Gawriluk et al. (2011) \\
\hline Casp2 & Cysteine protease & Increased number of primordial follicles & Bergeron et al. (1998) \\
\hline Mcl1 & $\mathrm{Bcl} 2$ family of apoptosis regulators & Expressed in oocytes during follicle formation & Hartley et al. (2002) \\
\hline
\end{tabular}

apoptosis and cyst breakdown (Greenfeld et al. 2007). These results support the model that apoptosis is required for germ cell cyst breakdown. MCL1 has been detected in human oocytes at the time of follicle formation though its role in the control of oocyte numbers has not been characterized yet (Hartley et al. 2002). Caspases act downstream of the BCL2 apoptosis regulators to execute programmed cell death. There are several caspases and one, caspase 2, when disrupted, results in an increased number of primordial follicles (Bergeron et al. 1998).

Programmed cell death can occur by mechanisms other than apoptosis, such as autophagy and necrosis. While there is evidence that apoptosis occurs in perinatal oocytes, recent work has also implicated autophagy as a cell death mechanism during cyst breakdown. Autophagy involves the degradation of intercellular components using the lysosomal machinery (Edinger \& Thompson 2004). Lysosomal amplification has been observed in oocytes at the time of primordial follicle formation, suggesting that autophagy may occur in newborn ovaries (Rodrigues et al. 2009). Newborn female mice with targeted disruption of two different genes (Atg7 and Becn1) encoding proteins involved in autophagy have a greater decrease in oocyte number than wild-type mice supporting a role for autophagy in the regulation of oocyte survival (Gawriluk et al. 2011).

\section{Growth factors and signaling molecules}

Several growth factors appear to be important for follicle formation (Table 2). Ovary organ culture studies have revealed a potential role for stem cell factor (SCF) in primordial follicle formation. When SCF is added to neonatal hamster ovaries in organ culture, primordial follicle formation is accelerated while an antibody against SCF inhibits follicle formation (Wang \& Roy 2004). SCF and its receptor, the c-KIT receptor tyrosine kinase, have been well studied during several phases of ovarian development. Mice mutant for either Scf or c-Kit have defects in PGC migration and proliferation (Reith et al. 1990, Huang et al. 1993, Bedell et al. 1995). KIT signaling is also important for follicle activation and later follicular survival (Yoshida et al. 1997, Parrott \& Skinner 1999, Reynaud et al. 2001). Injection of neonatal mice with ACK2, an antibody against C-KIT that blocks its action, beginning at PND1 had no effect on cyst breakdown or primordial follicle formation (Yoshida et al. 1997). However, recent work has shown that cyst breakdown begins as early as $17.5 \mathrm{dpc}$ (Pepling et al. 2010), so blocking KIT at PND1 may be too late to affect cyst breakdown and follicle formation.

Another group of growth factors, neurotrophins, have also been implicated in primordial follicle formation. Nerve growth factor (NGF) signals through its receptor, neurotrophic tyrosine kinase receptor, type 1 (NTRK1) also known as TRKA. Ngf or Ntrk1 homozygous mutants have fewer primordial follicles and more oocytes still in germ cell cysts (Dissen et al. 2001, Kerr et al. 2009). Two related growth factors are neurotrophin 4 (NT4) and brain-derived neurotrophic factor (BDNF) and both signal through NTRK2 also known as TRKB. Blocking NT4 or BDNF in organ culture results in a reduction of neonatal oocyte survival (Spears et al. 2003). Ntrk2 mutants also have fewer oocytes and, in addition, primordial follicle formation is reduced (Kerr et al. 2009).

There is evidence that several signaling pathways are important for follicle assembly (Table 2 ) including members of the transforming growth factor beta (TGFB) superfamily (Trombly et al. 2009). Mutants for either bone morphogenetic protein 15 (Bmp15) or growth differentiation factor 9 (Gdf9) have ovaries with a significant proportion of multiple oocyte follicles (MOFs; Yan et al. 2001). Normal follicles consist of one oocyte enclosed in granulosa cells while MOFs are abnormal follicles with more than one oocyte per follicle (Kent 1960). MOFs are thought to be oocyte cysts that did not completely break apart during cyst breakdown (Jefferson et al. 2006). Both BMP15 and GDF9 are secreted by the oocyte early in ovarian differentiation, suggesting that signals from the oocyte to the granulosa cells are important for cyst breakdown and follicle formation (Elvin et al. 2000). Supporting the involvement of GDF9 in follicle formation, addition of GDF9 to hamster ovaries in organ culture promotes the formation of follicles (Wang \& Roy 2004). Mouse ovaries exposed to another TGFB family member, activin A, have an increased number of primordial follicles (Bristol-Gould et al. 2006). Supporting the role of activin in primordial follicle formation, more MOFs are observed in mice that overexpress the activin antagonist, inhibin B (McMullen et al. 2001). In addition, activin subunit expression is 
Table 2 Growth factors and signaling molecules implicated in follicle assembly.

\begin{tabular}{|c|c|c|c|c|}
\hline Genes & Protein/function & Evidence for role in follicle assembly & Expressed in & References \\
\hline Activin A & TGFB family member & Promotes follicle formation & $\begin{array}{l}\text { Oocytes and granulosa } \\
\text { cells }\end{array}$ & $\begin{array}{l}\text { McMullen etal. (2001) and } \\
\text { Bristol-Gould et al. } \\
\text { (2006) }\end{array}$ \\
\hline Akt1 & $\begin{array}{l}\text { Serine/threonine kinase, also } \\
\text { known as protein kinase B } \\
\text { (PKB) }\end{array}$ & Multiple oocyte follicles & $\begin{array}{l}\text { Oocytes and granulosa } \\
\text { cells }\end{array}$ & Brown et al. (2010) \\
\hline Amh & $\begin{array}{l}\text { Anti-Mullerian hormone, TGFB } \\
\text { family member }\end{array}$ & $\begin{array}{l}\text { Follicle formation is reduced and oocyte } \\
\text { number increased in mutants }\end{array}$ & Stromal cells & Nilsson et al. (2011) \\
\hline Bdnf & $\begin{array}{l}\text { Brain-derived neurotrophic } \\
\text { factor, neurotrophin signaling }\end{array}$ & $\begin{array}{l}\text { Blocking in organ culture results in a } \\
\text { reduction of neonatal oocyte survival }\end{array}$ & ND & Spears et al. (2003) \\
\hline Bmp15 & $\begin{array}{l}\text { Bone morphogenetic protein } \\
15, \text { TGFB family member }\end{array}$ & Mutants have multiple oocyte follicles & Oocytes & Yan et al. (2001) \\
\hline Ctgf & $\begin{array}{l}\text { Connective tissue growth } \\
\text { factor, CCN protein family } \\
\text { member }\end{array}$ & Promotes follicle formation & Oocytes & Schindler et al. (2010) \\
\hline Follistatin & $\begin{array}{l}\text { Activin antagonist, TGFB family } \\
\text { member }\end{array}$ & $\begin{array}{l}\text { Reduced fertility, reduced follicle } \\
\text { formation }\end{array}$ & $\begin{array}{l}\text { Oocytes, granulosa, } \\
\text { and stromal cells }\end{array}$ & Kimura et al. (2011) \\
\hline Gdf9 & $\begin{array}{l}\text { Growth differentiation factor } 9, \\
\text { TGFB family member }\end{array}$ & Mutants have multiple oocyte follicles & Oocytes & Yan et al. (2001) \\
\hline Inhibin $\alpha$ & $\begin{array}{l}\text { Activin antagonist, TGFB family } \\
\text { member }\end{array}$ & $\begin{array}{l}\text { Overexpression causes multiple oocyte } \\
\text { follicles }\end{array}$ & ND & McMullen et al. (2001) \\
\hline Jagged1 & Notch ligand & $\begin{array}{l}\text { Inhibition of Notch signaling reduces } \\
\text { follicle formation }\end{array}$ & Oocytes & Trombly et al. (2008) \\
\hline Jagged2 & Notch ligand & $\begin{array}{l}\text { Inhibition of Notch signaling reduces } \\
\text { follicle formation }\end{array}$ & ND & Trombly et al. (2008) \\
\hline Lunatic fringe & Regulator of Notch signaling & Mutants have multiple oocyte follicles & Granulosa cells & Hahn et al. (2005) \\
\hline Ngf & $\begin{array}{l}\text { Nerve growth factor, neurotro- } \\
\text { phin signaling }\end{array}$ & Follicle formation is reduced in mutants & $\begin{array}{l}\text { Oocytes and granulosa } \\
\text { cells }\end{array}$ & $\begin{array}{l}\text { Dissen et al. (2001) and } \\
\quad \text { Abir et al. (2005) }\end{array}$ \\
\hline Notch1 & Notch receptor & $\begin{array}{l}\text { Inhibition of Notch signaling reduces } \\
\text { follicle formation }\end{array}$ & ND & Trombly et al. (2008) \\
\hline Notch2 & Notch receptor & $\begin{array}{l}\text { Inhibition of Notch signaling reduces } \\
\text { follicle formation }\end{array}$ & Granulosa cells & Trombly et al. (2008) \\
\hline NT4 & $\begin{array}{l}\text { Neurotrophin } 4 \text {, neurotrophin } \\
\text { signaling }\end{array}$ & $\begin{array}{l}\text { Blocking in organ culture results in a } \\
\text { reduction of neonatal oocyte survival }\end{array}$ & ND & Spears et al. (2003) \\
\hline Ntrk1 & $\begin{array}{l}\text { NGF receptor, neurotrophin } \\
\text { signaling }\end{array}$ & Follicle formation is reduced in mutants & $\begin{array}{l}\text { Oocytes and somatic } \\
\text { cells }\end{array}$ & Kerr et al. (2009) \\
\hline Ntrk2 & $\begin{array}{l}\text { Receptor for NT4 and BDNF, } \\
\text { neurotrophin signaling }\end{array}$ & $\begin{array}{l}\text { Follicle formation and germ cell number } \\
\text { is reduced in mutants }\end{array}$ & Oocytes & $\begin{array}{l}\text { Spears et al. (2003) and } \\
\text { Kerr et al. (2009) }\end{array}$ \\
\hline p27 & $\begin{array}{l}\text { Cyclin-dependent kinase } \\
\text { inhibitor 1, downstream of } \\
\text { PI3K signaling }\end{array}$ & $\begin{array}{l}\text { Primordial follicle formation is acceler- } \\
\text { ated in mutants }\end{array}$ & $\begin{array}{l}\text { Oocytes and granulosa } \\
\text { cells }\end{array}$ & Rajareddy et al. (2007) \\
\hline Scf & Stem cell factor, kit signaling & Promotes follicle formation in hamster & Granulosa cells & $\begin{array}{l}\text { Wang \& Roy (2004) and } \\
\text { Nandedkar et al. (2007) }\end{array}$ \\
\hline
\end{tabular}

ND, detected in ovary by RT-PCR but cell type not determined.

reduced in neonatal mice treated with estrogen, which blocks cyst breakdown (see Hormones section; Kipp et al. 2007). Mutants of another activin antagonist, follistatin, also have defects in oocyte development including a delay in cyst breakdown and follicle formation (Kimura et al. 2011). The TGFB family member, TGFB1, itself does not appear to play a role in follicle assembly but does interact with connective tissue growth factor (CTGF), which promotes follicle assembly in rat ovary organ culture (Schindler et al. 2010). The final TGFB family member that has been implicated in follicle assembly is anti-Mullerian hormone (AMH). Primordial follicle assembly is reduced in newborn rat ovaries treated with $\mathrm{AMH}$ while oocyte number is greater than controls (Nilsson et al. 2011). This suggests that $\mathrm{AMH}$ would normally maintain oocytes in cysts before follicle formation. Interestingly, $\mathrm{AMH}$ is expressed in stromal cells that have not previously been linked to follicle formation.

There is growing evidence that Notch signaling is important for the regulation of primordial follicle formation. The first suggestion that Notch signaling might be involved in follicle formation came from analysis of lunatic fringe ( $L f n g$ ) mutants (Hahn et al. 2005). LFNG is part of the Fringe family of proteins that regulate Notch signaling (Bruckner et al. 2000, Hicks et al. 2000). Lfng mutants are sterile and have ovaries with MOFs. The role of Fringe appears to be conserved as fringe mutants in Drosophila also have egg chambers with more than one oocyte (Grammont \& Irvine 2001). There are four Notch receptors (Notch 1-4) and five Notch ligands (Jagged1 and 2 and Delta-like (DLL) 1, 3, and 4) in mammals (Bray 2006). Mouse knockouts have been generated for all of these genes (Conlon et al. 1995, 
Hrabe de Angelis et al. 1997, Jiang et al. 1998, Xue et al. 1999, Krebs et al. 2000, 2003, 2004, McCright et al. 2001, Dunwoodie et al. 2002) but have not shed light on their role in follicle formation because they are either embryonic lethal or do not affect fertility at all. Primordial follicle formation is reduced in organ culture when Notch signaling is inhibited (Trombly et al. 2008). Notch3, Notch4, and D/l3 mutants are fertile and D/l1 and D/l4 are not expressed in neonatal ovaries, suggesting that these molecules do not play a role in follicle assembly. Generations of Notch1, Notch2, Jagged1, and Jagged2 tissue-specific knockouts will be necessary to determine which Notch ligands and receptors are important for follicle formation.

Signaling through the phosphoinositide-3-kinase (PI3K) pathway may be a mechanism used in follicle formation. The PI3K pathway activates AKT and AKT in turn can phosphorylate several proteins including TSC1/2, MTOR, FOXO3, and CDK1/p27. Akt1 mouse knockout ovaries contain MOFs, indicating a role for the PI3K pathway in cyst breakdown (Brown et al. 2010). Further, inhibition of AKT in neonatal rat ovary organ culture resulted in decreased CDK1/p27 expression and decreased phosphorylated FOXO3a and was associated with reduced oocyte apoptosis (Liu et al. 2009). It is not, however, likely that FOXO3a is involved in cyst breakdown as FOXO3a knockouts demonstrate normal primordial follicle formation (John et al. 2007). However, CDK1/p27 knockout mice show accelerated primordial follicle formation and CDK1/p27 is expressed in somatic cells surrounding cysts (Rajareddy et al. 2007). TSC $1 / 2$ and MTOR may be activated during cyst breakdown within oocytes. Few studies have examined the role of these molecules in follicle development, but TSC1 was recently shown to be important in primordial follicle activation using TsC1 knockout mice (Adhikari et al. 2010). Oocyte-specific knockouts of Tsc1 or Pten (a negative regulator of $\mathrm{PI} 3 \mathrm{~K}$ signaling) undergo normal primordial follicle formation (Reddy et al. 2008, Adhikari et al. 2010). However, in these studies, the Gdf9 promoter was used to drive Cre recombinase in oocytes, and this promoter is not active until PND3 after most cysts have already broken down (Lan et al. 2004). Therefore, more work is needed to determine the effects of the PI3K pathway in cyst breakdown.

\section{Transcription factors}

Several nuclear factors appear to be important for primordial follicle formation (Table 3). Mutants of the gene encoding the aryl hydrocarbon receptor (AHR), a basic helix loop helix (BHLH) transcription factor, form follicles at a faster rate than normal (Benedict et al. 2000, Robles et al. 2000). Mutants of factor in germ line alpha (Figla/Mhm), also encoding a BHLH protein, begin to lose oocytes at birth and oocytes still present are not enclosed in primordial follicles (Soyal et al. 2000). Disruption of Nobox, an oocyte-specific homeobox gene, results in increased oocyte loss and a delay in cyst breakdown (Suzumori et al. 2002, Rajkovic et al. 2004). Mutants in Foxl2, a winged-helix forkhead transcription factor, are sterile with germ cell cysts that do not break down (Uda et al. 2004). Finally, siRNA knockdown of heterogeneous nuclear ribonucleoprotein $\mathrm{K}$ (HNRNPK) in rat ovary organ culture caused a block in cyst breakdown and follicle formation (Wang et al. 2011). Identifying the targets of these transcription factors will greatly add to our understanding of the mechanisms of primordial follicle assembly.

\section{Hormones}

Neonatal female mice treated with estradiol $\left(\mathrm{E}_{2}\right.$; Iguchi et al. 1986), with synthetic estrogens such as diethylstilbestrol (DES; Iguchi et al. 1990) or bisphenol-A (BPA; Suzuki et al. 2002) or with the phytoestrogen genistein (Jefferson et al. 2002), have more MOFs as adults, which are likely oocyte cysts that did not separate and became enclosed in follicles (Gougeon 1981, Iguchi \& Takasugi 1986, Iguchi et al. 1986). One model is that normally, high levels of $E_{2}$ in the fetal ovary keeps oocytes in cysts and that late in fetal development, $E_{2}$ levels drop resulting in cyst breakdown (Chen et al. 2007). When oocytes are exposed to estrogens, cyst breakdown is

Table 3 Transcription factors active during follicle assembly.

\begin{tabular}{|c|c|c|c|c|}
\hline Genes & Protein/function & Evidence for role in follicle assembly & Expressed in & References \\
\hline Ahr & $\begin{array}{l}\text { Aryl hydrocarbon receptor, basic } \\
\text { helix-loop-helix transcription factor }\end{array}$ & $\begin{array}{l}\text { Primordial follicle formation is } \\
\text { accelerated in mutants }\end{array}$ & $\begin{array}{l}\text { Oocytes and granulosa } \\
\text { cells }\end{array}$ & $\begin{array}{l}\text { Benedict et al. (2000) and } \\
\text { Robles et al. (2000) }\end{array}$ \\
\hline Figla & $\begin{array}{l}\text { Factor in the germ line alpha, } \\
\text { folliculogenesis-specific basic } \\
\text { helix-loop-helix }\end{array}$ & $\begin{array}{l}\text { Mutants are defective in follicle } \\
\text { formation and exhibit perinatal } \\
\text { oocyte loss }\end{array}$ & Oocytes & Soyal et al. (2000) \\
\hline Foxl2 & $\begin{array}{l}\text { Forkhead box } \mathrm{L} 2 \text {, winged helix } \\
\text { transcription factor }\end{array}$ & $\begin{array}{l}\text { Mutants are defective in follicle } \\
\text { formation and exhibit perinatal } \\
\text { oocyte loss }\end{array}$ & Granulosa cells & $\begin{array}{l}\text { Schmidt et al. (2004) and } \\
\text { Uda et al. (2004) }\end{array}$ \\
\hline Hnrnpk & $\begin{array}{l}\text { Heterogeneous nuclear ribo- } \\
\text { nucleoprotein } \mathrm{K}\end{array}$ & $\begin{array}{l}\text { siRNA knockdown in rat ovary organ } \\
\text { culture caused a block in cyst } \\
\text { breakdown and follicle formation }\end{array}$ & $\begin{array}{l}\text { Oocytes and granulosa } \\
\text { cells }\end{array}$ & Wang et al. (2011) \\
\hline Nobox & $\begin{array}{l}\text { Newborn ovary homeobox- } \\
\text { encoding gene }\end{array}$ & $\begin{array}{l}\text { Mutants have delayed follicle } \\
\text { formation and oocyte loss }\end{array}$ & Oocytes & Rajkovic et al. (2004) \\
\hline
\end{tabular}


inhibited. Supporting this, genistein-treated mice had more oocytes in cysts compared with controls (Jefferson et al. 2006). These findings are consistent with the idea that exposure to estrogens inhibits cyst breakdown.

Estrogens function via nuclear receptors, members of the steroid hormone receptor superfamily. Mammals have least two estrogen receptors (ERs), ER $\alpha$ and $E R \beta$, containing a conserved DNA-binding domain (Pettersson \& Gustafsson 2001). After ligand binding, a conformational change leads to ER dimerization and interaction with the target DNA sequence called the estrogen response element (ERE). The receptor dimer then recruits coregulators that interact with basal transcription factors and either stimulate or inhibit transcription of target genes. Besides 'classical' steroid hormone signaling, several other signaling mechanisms can occur including tethered, ligand-independent, and membrane signaling (Heldring et al. 2007). In tethered signaling, estrogen activates ERs, which then interact with other transcription factors that bind to target sequences but the ER does not directly bind to the DNA (Kushner et al. 2000, Saville et al. 2000). For ligand-independent signaling, ERs are phosphorylated by activation of other signaling pathways and then bind to EREs to modulate target gene transcription without being activated by ligand binding (Kato et al. 1995). There are at least two ways estrogen can signal through the membrane. First, nuclear ERs can be translocated to and act at the plasma membrane (Pedram et al. 2006). Secondly, estrogen may signal through membranebound receptors ( $\mathrm{mERs}$ ) including a $\mathrm{G}$ protein-coupled membrane receptor called GPR30 (Revankar et al. 2005). GPR30 is thought to be coupled to $\mathrm{G} \alpha_{\mathrm{s}}$ (Thomas et al. 2005) and estrogen acting through GPR30 activates MAPK and PI3K signaling (Maggiolini \& Picard 2010). Another mER agonist, STX (diphenyl acrylamide), selectively targets a $\mathrm{G} \alpha_{\mathrm{q}}$-associated protein and also activates MAPK and PI3K signaling (Qiu et al. 2006, Lin et al. 2009). It is unclear whether STX is a GPR30 agonist or whether it signals via another unidentified mER (Lin et al. 2009). Evidence for other estrogenresponsive $G$ protein-coupled receptors exists but they have not yet been well characterized (Hasbi et al. 2005).

Neonatal genistein treatment causes the appearance of MOFs in adult ovaries. To determine which ER genistein was signaling through, Jefferson et al. (2002) exposed $E R$ mutants to genistein as neonates and examined effects on the adult ovary. MOFs were still observed in ESR1 but not ESR2 mutant adult females, suggesting that these effects are mediated through ESR2 (Jefferson et al. 2002). ESR2 mutant adult females have reduced fertility with fewer litters and pups per litter (Krege et al. 1998). Mutant adult ovaries have more atretic follicles and fewer corpora lutea, suggesting that more oocytes are dying. ESR1 mutants are sterile with ovaries lacking corpora lutea and containing hemorrhagic follicles (Lubahn et al. 1993). It is not known whether defects in the adult ovaries of either $E R$ mutant result from problems with follicle development or earlier, during cyst breakdown. ESR2 is expressed in granulosa cells and ESR1 in theca cells of adult ovaries, and mRNAs corresponding to both are detected in developing ovaries (Jefferson et al. 2000).

When neonatal oocytes are exposed to estrogens, cyst breakdown is inhibited but it is unclear which estrogen receptor is used (Chen et al. 2007). During cyst breakdown, ESR1 is expressed in pregranulosa cells and ESR2 in some oocyte nuclei (Chen et al. 2009). In addition, ESR1 or ESR2 agonists inhibit cyst breakdown, suggesting that estrogen can signal through either receptor to regulate cyst breakdown. However, ER knockouts have no effect on neonatal oocyte development ( $F$ Tang \& M Pepling, unpublished observations). These results suggest that estrogen signals via another receptor to maintain oocytes in cysts. $E_{2}$ can signal at the membrane to block cyst breakdown supporting the idea that a membrane receptor is involved (Chen et al. 2009). Gpr30 knockout mice are fertile with no observable reproductive defects making it an unlikely candidate as the $\mathrm{mER}$ in neonatal ovaries (Otto et al. 2009).

The source of $E_{2}$ maintaining oocytes in cysts is unknown. Cyst breakdown begins a few days before birth in the inner cortex of the ovaries (Pepling et al. 2010), and thus, $E_{2}$ levels should drop at this time. The source of $E_{2}$ may be the maternal circulation. However, in humans, $E_{2}$ levels are rising during primordial follicle formation, and in cows, levels are low prior to follicle formation suggesting that maternal circulating $E_{2}$ is not the source in these species (Senger 2003). Alternatively, fetal ovaries could produce $E_{2}$ and cyst breakdown could begin when levels of fetal $E_{2}$ secretion fall. Fetal cow ovaries produce $E_{2}$ and levels drop when primordial follicles begin to form (Yang \& Fortune 2008, Nilsson \& Skinner 2009).

Unlike rodents and cows, estrogen seems to have a positive effect on follicle formation in some species. In the hamster, estrogen has been shown to promote follicle assembly (Wang \& Roy 2007, Wang et al. 2008). In the baboon, when estrogen production is blocked, cyst breakdown and follicle assembly are disrupted (Zachos et al. 2002). It is not known why estrogen promotes follicle formation in some species and inhibits follicle formation in others. It may be that high estrogen concentrations inhibit follicle assembly while low concentrations promote assembly (Nilsson \& Skinner 2009). Alternatively, there may be species differences in estrogen signaling.

Neonatal treatment with progesterone also results in more MOFs in adult females (Iguchi et al. 1986). Subsequently, neonatal progesterone treatment was shown to reduce primordial follicle assembly in rats supporting the idea that progesterone, like estrogen, acts during neonatal oocyte development (Kezele \& Skinner 2003). Progesterone treatment of neonatal mouse ovaries reduced cyst breakdown (Chen et al. 2007). Since progesterone can be converted to estrogen, its 
effect could be exerted either directly or via conversion to estrogen. However, a non-metabolizable version of progesterone, promegestone, also inhibited cyst breakdown and follicle assembly. A non-metabolizable progesterone analog blocked follicle formation in rat ovaries as well (Nilsson et al. 2006). Like estrogen, there are several possible sources of progesterone. Two studies using the bovine model have demonstrated that progesterone is produced by the fetal ovary (Yang \& Fortune 2008, Nilsson \& Skinner 2009). One study reported a drop in fetal ovarian progesterone while progesterone in the fetal or maternal circulation did not change (Nilsson \& Skinner 2009).

Progesterone can signal through the nuclear progesterone receptor (PR) that has two isoforms, PR-A and PR-B that are transcribed from a single gene using two different promoters (Conneely et al. 1989, Kastner et al. 1990). Both PR isoforms are found in the adult ovary, in theca cells, and in granulosa cells (Gava et al. 2004). The $P R$ knockout results in female infertility with defects in reproductive tissues including the ovary, uterus, and mammary glands (Lydon et al. 1995). PR-A-specific knockouts exhibit defects in ovarian and uterine function while $P R$ - $B$-specific knockouts have defects in mammary gland function (Mulac-Jericevic et al. 2000, 2003). While progesterone inhibits follicle development (Kezele \& Skinner 2003), follicles develop normally in $P R$ knockouts suggesting an alternative signaling mechanism (Lydon et al. 1996). Progesterone can also signal through membrane receptors by at least three mechanisms (Peluso 2006). First, one of the nuclear isoforms could be translocated to the nucleus. Secondly, a seven-transmembrane spanning family of PRs called progestin and adipoQ receptors (PAQR) has been identified with members in three groups, $\alpha, \beta$, and $\gamma$. Thirdly, two single membrane-spanning proteins called progesterone receptor membrane component (PGRMC) 1 and PGRMC2 can act as PRs in complex with other proteins. While there is evidence that these proteins are present in the adult ovary (Cai \& Stocco 2005, Peluso 2006), their expression in the developing mouse ovary has not been examined. In a recent study, PGRMC1 and PGRMC2 were detected in neonatal rat ovaries by microarray analysis and RT-PCR (Nilsson et al. 2006).

Exposure of neonates to testosterone also causes more MOFs in adult ovaries (Iguchi et al. 1986). However, this may be due to conversion of testosterone to estrogen because inhibiting estrogen synthesis from testosterone eliminated the higher incidence of MOFs (Iguchi et al. 1988). Effects of testosterone directly on cyst breakdown have not been tested. Testosterone signals through the androgen receptor (AR) belonging to the nuclear steroid hormone receptor family (Roy et al. 1999). Like other steroid hormone receptors, testosterone can also signal through receptors at the membrane (Heinlein \& Chang 2002).
Follicle-stimulating hormone (FSH) may also be involved in follicle assembly. FSH is present in the serum of neonatal mice and hamsters (Vomachka \& Greenwald 1979, Halpin et al. 1986) and the FSH receptor is detected using RT-PCR in neonatal mouse ovaries (O'Shaughnessy et al. 1994). Inactivation of FSH using an anti-FSH antibody results in the inhibition of primordial follicle formation in the hamster (Roy \& Albee 2000), while addition of FSH to cultured ovaries results in acceleration of primordial follicle formation (Wang \& Roy 2004). A recent study using mouse ovary organ culture also implicates FSH in promoting cyst breakdown and primordial follicle formation (Lei et al. 2010). However, Fsh or Fsh receptor knockout female mice while infertile undergo normal primordial follicle formation and follicle development is not arrested until the preantral stage (Kumar et al. 1997, Dierich et al. 1998, Abel et al. 2000).

\section{Links between meiotic progression and follicle formation}

Though diplotene arrest and follicle formation occur during the same time frame, their relationship is unclear. Two structural components of the synaptonemal complex found at the pachytene stage, synaptonemal complex protein (SYCP) 1 and SYCP3, are important for normal oocyte development. Inhibition of SYCP1 in rats resulted in premature arrival of oocytes at the diplotene stage and premature primordial follicle assembly suggesting a link between cell cycle stage and primordial follicle formation (Paredes et al. 2005). In mice, Sycp1 mutants are sterile and females lack oocytes but follicle formation was not examined (de Vries et al. 2005). Sycp3 mutants are subfertile and while oocytes appear to develop normally, chromosome segregation is defective (Yuan et al. 2002). In cows, while follicles form before the oocytes reach diplotene arrest, they do not develop to the primary follicle stage until they arrest in diplotene again linking follicle development and meiotic stage. Primordial follicle activation can be inhibited by estrogen, which fetal bovine ovaries produce around the time of follicle formation (Yang \& Fortune 2008). In the cow, estrogen may block follicle activation by inhibiting meiotic progression. Supporting the idea that estrogen can affect meiotic progression, bisphenol A (BPA) treatment of mouse embryos caused defects in meiosis (Susiarjo et al. 2007). ESR2 mutants had meiotic defects similar to BPA-treated animals, suggesting that BPA acts as an ESR2 antagonist.

\section{Cell adhesion molecules}

Cell adhesion molecules (CAMs) likely play important roles in oocyte development. Before birth, CAMs may be important in keeping oocytes in germ cell cysts. 
These CAMs would be downregulated to allow cysts to break apart. A different set of CAMs might be important for adhesion between oocytes and granulosa cells during primordial follicle formation. Recent work using the hamster model has implicated $\mathrm{N}$ - and $\mathrm{E}$-cadherin in follicle formation (Wang \& Roy 2010). E-cadherin was detected in oocytes within germ cell cysts and in primordial follicles. Blocking E-cadherin using an inhibitory antibody resulted in accelerated follicle formation suggesting that, normally, E-cadherin is involved in maintaining oocytes in cysts. N-cadherin, on the other hand, was detected in granulosa cells as primordial follicles formed and treatment of ovaries in organ culture with an $\mathrm{N}$-cadherin-blocking antibody resulted in reduced follicle formation.

\section{Conclusions and perspectives}

The pool of primordial follicles, which is formed early in the life of mammalian species, is important for reproductive success. Progress has been made in elucidating the mechanisms by which primordial follicles are assembled. Proteins classified as programmed cell death regulators, growth factors, signaling molecules, transcription factors, hormones, meiotic regulators, and CAMs have been implicated in primordial follicle formation. Understanding how all these factors work together to establish the primordial follicle pool will shed light on female reproductive disorders such as premature ovarian failure, reproductive lifespan, menopause, and ovarian cancer.

\section{Declaration of interest}

The author declares that there is no conflict of interest that could be perceived as prejudicing the impartiality of this review.

\section{Funding}

Research in the author's laboratory is supported by bridge funds from Syracuse University, New York, NY, USA.

\section{Acknowledgements}

The author thanks Robin Jones for providing Fig. 2.

\section{References}

Abel MH, Wootton AN, Wilkins V, Huhtaniemi I, Knight PG \& Charlton HM 2000 The effect of a null mutation in the follicle-stimulating hormone receptor gene on mouse reproduction. Endocrinology 141 1795-1803. (doi:10.1210/en.141.5.1795)

Abir R, Fisch B, Jin S, Barnnet $M$, Ben-Haroush A, Felz C, KesslerIcekson G, Feldberg D, Nitke S \& Ao A 2005 Presence of NGF and its receptors in ovaries from human fetuses and adults. Molecular Human Reproduction 11 229-236. (doi:10.1093/molehr/gah164)

Adhikari D, Zheng W, Shen Y, Gorre N, Hamalainen T, Cooney AJ, Huhtaniemi I, Lan ZJ \& Liu K 2010 Tsc/mTORC1 signaling in oocytes governs the quiescence and activation of primordial follicles. Human Molecular Genetics 19 397-410. (doi:10.1093/hmg/ddp483)
Bedell MA, Brannan CI, Evans EP, Copeland NG, Jenkins NA \& Donovan PJ 1995 DNA rearrangements located over $100 \mathrm{~kb} 5^{\prime}$ of the Steel (SI)-coding region in Steel-panda and Steel-contrasted mice deregulate SI expression and cause female sterility by disrupting ovarian follicle development. Genes and Development 9 455-470. (doi:10.1101/gad.9.4.455)

Benedict JC, Lin TM, Loeffler IK, Peterson RE \& Flaws JA 2000 Physiological role of the aryl hydrocarbon receptor in mouse ovary development. Toxicological Sciences 56 382-388. (doi:10.1093/toxsci/ 56.2.382)

Bergeron L, Perez GI, Macdonald G, Shi L, Sun Y, Jurisicova A, Varmuza S, Latham KE, Flaws JA, Salter JC et al. 1998 Defects in regulation of apoptosis in caspase-2-deficient mice. Genes and Development 12 1304-1314. (doi:10.1101/gad.12.9.1304)

Borum K 1961 Oogenesis in the mouse. A study of the origin of the mature ova. Experimental Cell Research 45 39-47. (doi:10.1016/0014-4827 (67) $90110-3)$

Bray SJ 2006 Notch signalling: a simple pathway becomes complex. Nature Reviews. Molecular Cell Biology 7 678-689. (doi:10.1038/nrm2009)

Bristol-Gould SK, Kreeger PK, Selkirk CG, Kilen SM, Cook RW, Kipp JL, Shea LD, Mayo KE \& Woodruff TK 2006 Postnatal regulation of germ cells by activin: the establishment of the initial follicle pool. Developmental Biology 298 132-148. (doi:10.1016/j.ydbio.2006.06. 025)

Brown C, LaRocca J, Pietruska J, Ota M, Anderson L, Smith SD, Weston P, Rasoulpour T \& Hixon ML 2010 Subfertility caused by altered follicular development and oocyte growth in female mice lacking PKB alpha/Akt1. Biology of Reproduction 82 246-256. (doi:10.1095/biolreprod.109. 077925)

Bruckner K, Perez L, Clausen H \& Cohen S 2000 Glycosyltransferase activity of Fringe modulates Notch-Delta interactions. Nature 406 411-415. (doi:10.1038/35019075)

Byskov AG 1986 Differentiation of mammalian embryonic gonad. Physiological Reviews 66 71-117.

Byskov AG, Guoliang X \& Andersen CY 1997 The cortex-medulla oocyte growth pattern is organized during fetal life: an in vitro study of the mouse ovary. Molecular Human Reproduction 3 795-800. (doi:10.1093/ molehr/3.9.795)

Cai Z \& Stocco C 2005 Expression and regulation of progestin membrane receptors in the rat corpus luteum. Endocrinology 146 5522-5532. (doi:10.1210/en.2005-0759)

Chen Y, Jefferson WN, Newbold RR, Padilla-Banks E \& Pepling ME 2007 Estradiol, progesterone, and genistein inhibit oocyte nest breakdown and primordial follicle assembly in the neonatal mouse ovary in vitro and in vivo. Endocrinology 148 3580-3590. (doi:10.1210/en.20070088)

Chen Y, Breen K \& Pepling ME 2009 Estrogen can signal through multiple pathways to regulate oocyte cyst breakdown and primordial follicle assembly in the neonatal mouse ovary. Journal of Endocrinology 202 407-417. (doi:10.1677/JOE-09-0109)

Conlon RA, Reaume AG \& Rossant J 1995 Notch1 is required for the coordinate segmentation of somites. Development 121 1533-1545.

Conneely OM, Kettelberger DM, Tsai MJ, Schrader WT \& O'Malley BW 1989 The chicken progesterone receptor A and B isoforms are products of an alternate translation initiation event. Journal of Biological Chemistry 264 14062-14064.

de Cuevas M, Lilly MA \& Spradling AC 1997 Germline cyst formation in Drosophila. Annual Review of Genetics 31 405-428. (doi:10.1146/ annurev.genet.31.1.405)

De Felici M, Di Carlo A, Pesce M, Iona S, Farrace MG \& Piacentini M 1999 $\mathrm{BCl}-2$ and Bax regulation of apoptosis in germ cells during prenatal oogenesis in the mouse embryo. Cell Death and Differentiation 6 908-915. (doi:10.1038/sj.cdd.4400561)

De Pol A, Vaccina F, Forabosco A, Cavazzuti E \& Marzona L 1997 Apoptosis of germ cells during human prenatal oogenesis. Human Reproduction 12 2235-2241. (doi:10.1093/humrep/12.10.2235)

Dierich A, Sairam MR, Monaco L, Fimia GM, Gansmuller A, LeMeur M \& Sassone-Corsi P 1998 Impairing follicle-stimulating hormone (FSH) signaling in vivo: targeted disruption of the FSH receptor leads to aberrant gametogenesis and hormonal imbalance. PNAS 95 13612-13617. (doi:10.1073/pnas.95.23.13612) 
Dissen GA, Romero C, Hirshfield AN \& Ojeda SR 2001 Nerve growth factor is required for early follicular development in the mammalian ovary. Endocrinology 142 2078-2086. (doi:10.1210/en.142.5.2078)

Dunwoodie SL, Clements M, Sparrow DB, Sa X, Conlon RA \& Beddington RS 2002 Axial skeletal defects caused by mutation in the spondylocostal dysplasia/pudgy gene DII3 are associated with disruption of the segmentation clock within the presomitic mesoderm. Development 129 1795-1806.

Edinger AL \& Thompson CB 2004 Death by design: apoptosis, necrosis and autophagy. Current Opinion in Cell Biology 16 663-669. (doi:10.1016/j. ceb.2004.09.011)

Elvin JA, Yan C \& Matzuk MM 2000 Oocyte-expressed TGF-beta superfamily members in female fertility. Molecular and Cellular Endocrinology 159 1-5. (doi:10.1016/S0303-7207(99)00185-9)

Flaws JA, Hirshfield AN, Hewitt JA, Babus JK \& Furth PA 2001 Effect of bcl-2 on the primordial follicle endowment in the mouse ovary. Biology of Reproduction 64 1153-1159. (doi:10.1095/biolreprod64.4.1153)

Gava N, Clarke CL, Byth K, Arnett-Mansfield RL \& deFazio A 2004 Expression of progesterone receptors $\mathrm{A}$ and $\mathrm{B}$ in the mouse ovary during the estrous cycle. Endocrinology 145 3487-3494. (doi:10.1210/en. 2004-0212)

Gawriluk TR, Hale AN, Flaws JA, Dillon CP, Green DR \& Rucker EB III 2011 Autophagy is a cell survival program for female germ cells in the murine ovary. Reproduction 141 759-765. (doi:10.1530/REP-100489)

Ghafari F, Gutierrez CG \& Hartshorne GM 2007 Apoptosis in mouse fetal and neonatal oocytes during meiotic prophase one. BMC Developmental Biology 7 87. (doi:10.1186/1471-213X-7-87)

Gondos B 1973 Intercellular bridges and mammalian germ cell differentiation. Differentiation 1 177-182.

Gougeon A 1981 Frequent occurrence of multiovular follicles and multinuclear oocytes in the adult human ovary. Fertility and Sterility 35 417-422.

Grammont M \& Irvine KD 2001 Fringe and Notch specify polar cell fate during Drosophila oogenesis. Development 128 2243-2253.

Greenfeld CR, Pepling ME, Babus JK, Furth PA \& Flaws JA 2007 BAX regulates follicular endowment in mice. Reproduction 133 865-876. (doi:10.1530/REP-06-0270)

Hahn KL, Johnson J, Beres BJ, Howard S \& Wilson-Rawls J 2005 Lunatic fringe null female mice are infertile due to defects in meiotic maturation. Development 132 817-828. (doi:10.1242/dev.01601)

Halpin DM, Jones A, Fink G \& Charlton HM 1986 Postnatal ovarian follicle development in hypogonadal (hpg) and normal mice and associated changes in the hypothalamic-pituitary ovarian axis. Journal of Reproduction and Fertility 77 287-296. (doi:10.1530/jrf.0.0770287)

Hartley PS, Bayne RA, Robinson LL, Fulton N \& Anderson RA 2002 Developmental changes in expression of myeloid cell leukemia-1 in human germ cells during oogenesis and early folliculogenesis. Journal of Clinical Endocrinology and Metabolism 87 3417-3427. (doi:10.1210/jc. 87.7.3417)

Hasbi A, O'Dowd BF \& George SR 2005 A G protein-coupled receptor for estrogen: the end of the search? Molecular Interventions 5 158-161. (doi:10.1124/mi.5.3.5)

Heinlein CA \& Chang C 2002 The roles of androgen receptors and androgen-binding proteins in nongenomic androgen actions. Molecular Endocrinology 16 2181-2187. (doi:10.1210/me.2002-0070)

Heldring N, Pike A, Andersson S, Matthews J, Cheng G, Hartman J, Tujague M, Strom A, Treuter E, Warner M et al. 2007 Estrogen receptors: how do they signal and what are their targets. Physiological Reviews 87 905-931. (doi:10.1152/physrev.00026.2006)

Hicks C, Johnston SH, diSibio G, Collazo A, Vogt TF \& Weinmaster G 2000 Fringe differentially modulates Jagged 1 and Delta 1 signalling through Notch1 and Notch2. Nature Cell Biology 2 515-520. (doi:10.1038/ 35019553)

Hirshfield AN \& DeSanti AM 1995 Patterns of ovarian cell proliferation in rats during the embryonic period and the first three weeks postpartum. Biology of Reproduction 53 1208-1221. (doi:10.1095/biolreprod53.5. 1208)

Hrabe de Angelis M, McIntyre J II \& Gossler A 1997 Maintenance of somite borders in mice requires the Delta homologue DII1. Nature 386 717-721. (doi:10.1038/386717a0)
Huang EJ, Manova K, Packer AI, Sanchez S, Bachvarova RF \& Besmer P 1993 The murine steel panda mutation affects kit ligand expression and growth of early ovarian follicles. Developmental Biology 157 100-109. (doi:10.1006/dbio.1993.1115)

Iguchi T \& Takasugi N 1986 Polyovular follicles in the ovary of immature mice exposed prenatally to diethylstilbestrol. Anatomica Embryologica 175 53-55. (doi:10.1007/BF00315455)

Iguchi T, Takasugi N, Bern HA \& Mills KT 1986 Frequent occurrence of polyovular follicles in ovaries of mice exposed neonatally to diethylstilbestrol. Teratology 34 29-35. (doi:10.1002/tera.1420340105)

Iguchi T, Todoroki R, Takasugi N \& Petrow V 1988 The effects of an aromatase inhibitor and a $5 \alpha$-reductase inhibitor upon the occurrence of polyovular follicles, persistent anovulation, and permanent vaginal stratification in mice treated neonatally with testosterone. Biology of Reproduction 39 689-697. (doi:10.1095/biolreprod39.3.689)

Iguchi T, Fukazawa Y, Uesugi Y \& Taksugi N 1990 Polyovular follicles in mouse ovaries exposed neonatally to diethylstilbestrol in vivo and in vitro. Biology of Reproduction 43 478-484. (doi:10.1095/biolreprod43.3.478)

Jefferson WN, Couse JF, Banks EP, Korach KS \& Newbold RR 2000 Expression of estrogen receptor beta is developmentally regulated in reproductive tissues of male and female mice. Biology of Reproduction 62 310-317. (doi:10.1095/biolreprod62.2.310)

Jefferson WN, Couse JF, Padilla-Banks E, Korach KS \& Newbold RR 2002 Neonatal exposure to genestein induces estrogen receptor (ER) $\alpha$ expression and multioocyte follicles in the maturing mouse ovary: evidence for ERß-mediated and nonestrogenic actions. Biology of Reproduction 67 1285-1296. (doi:10.1095/biolreprod67.4.1285)

Jefferson W, Newbold R, Padilla-Banks E \& Pepling M 2006 Neonatal genistein treatment alters ovarian differentiation in the mouse: inhibition of oocyte nest breakdown and increased oocyte survival. Biology of Reproduction 74 161-168. (doi:10.1095/biolreprod.105.045724)

Jiang R, Lan Y, Chapman HD, Shawber C, Norton CR, Serreze DV, Weinmaster G \& Gridley T 1998 Defects in limb, craniofacial, and thymic development in Jagged2 mutant mice. Genes and Development 12 1046-1057. (doi:10.1101/gad.12.7.1046)

John GB, Shirley LJ, Gallardo TD \& Castrillon DH 2007 Specificity of the requirement for Foxo3 in primordial follicle activation. Reproduction 133 855-863. (doi:10.1530/REP-06-0051)

Kastner P, Krust A, Turcotte B, Stropp U, Tora L, Gronemeyer H \& Chambon P 1990 Two distinct estrogen-regulated promoters generate transcripts encoding the two functionally different human progesterone receptor forms A and B. EMBO Journal 9 1603-1614.

Kato S, Endoh H, Masuhiro $Y$, Kitamoto T, Uchiyama S, Sasaki H, Masushige S, Gotoh Y, Nishida E, Kawashima H et al. 1995 Activation of the estrogen receptor through phosphorylation by mitogen-activated protein kinase. Science 270 1491-1494. (doi:10.1126/science.270. 5241.1491)

Kent HA 1960 Polyovular follicles and multinucleate ova in the ovaries of young mice. Anatomical Record 137 521-524. (doi:10.1002/ar.1091370411)

Kerr B, Garcia-Rudaz C, Dorfman M, Paredes A \& Ojeda SR 2009 NTRK1 and NTRK2 receptors facilitate follicle assembly and early follicular development in the mouse ovary. Reproduction 138 131-140. (doi:10. 1530/REP-08-0474)

Kezele P \& Skinner MK 2003 Regulation of ovarian primordial follicle assembly and development by estrogen and progesterone: endocrine model of follicle assembly. Endocrinology 144 3329-3337. (doi:10. 1210/en.2002-0131)

Kim MR \& Tilly JL 2004 Current concepts in Bcl-2 family member regulation of female germ cell development and survival. Biochimica et Biophysica Acta 1644 205-210. (doi:10.1016/j.bbamcr.2003.10.012)

Kimura F, Bonomi LM \& Schneyer AL 2011 Follistatin regulates germ cell nest breakdown and primordial follicle formation. Endocrinology 152 697-706. (doi:10.1210/en.2010-0950)

Kipp JL, Kilen SM, Bristol-Gould S, Woodruff TK \& Mayo KE 2007 Neonatal exposure to estrogens suppresses activin expression and signaling in the mouse ovary. Endocrinology 148 1968-1976. (doi:10.1210/en.20061083)

Krebs LT, Xue Y, Norton CR, Shutter JR, Maguire M, Sundberg JP, Gallahan D, Closson V, Kitajewski J, Callahan R et al. 2000 Notch signaling is essential for vascular morphogenesis in mice. Genes and Development 14 1343-1352. 
Krebs LT, Xue Y, Norton CR, Sundberg JP, Beatus P, Lendahl U, Joutel A \& Gridley T 2003 Characterization of Notch3-deficient mice: normal embryonic development and absence of genetic interactions with a Notch1 mutation. Genesis 37 139-143. (doi:10.1002/gene.10241)

Krebs LT, Shutter JR, Tanigaki K, Honjo T, Stark KL \& Gridley T 2004 Haploinsufficient lethality and formation of arteriovenous malformations in Notch pathway mutants. Genes and Development 18 2469-2473. (doi:10.1101/gad.1239204)

Krege JH, Hodgin JB, Couse JF, Enmark E, Warner M, Mahler JF, Sar M, Korach KS, Gustafsson JA \& Smithies O 1998 Generation and reproductive phenotypes of mice lacking estrogen receptor beta. PNAS 95 15677-15682. (doi:10.1073/pnas.95.26.15677)

Kumar TR, Wang Y, Lu N \& Matzuk MM 1997 Follicle stimulating hormone is required for ovarian follicle maturation but not male fertility. Nature Genetics 15 201-204. (doi:10.1038/ng0297-201)

Kushner PJ, Agard DA, Greene GL, Scanlan TS, Shiau AK, Uht RM \& Webb P 2000 Estrogen receptor pathways to AP-1. Journal of Steroid Biochemistry and Molecular Biology 74 311-317. (doi:10.1016/S09600760(00)00108-4)

Lan ZJ, Xu X \& Cooney AJ 2004 Differential oocyte-specific expression of Cre recombinase activity in GDF-9-iCre, Zp3cre, and Msx2Cre transgenic mice. Biology of Reproduction 71 1469-1474. (doi:10.1095/ biolreprod.104.031757)

Lei L, Jin S, Mayo KE \& Woodruff TK 2010 The interactions between the stimulatory effect of follicle-stimulating hormone and the inhibitory effect of estrogen on mouse primordial folliculogenesis. Biology of Reproduction 82 13-22. (doi:10.1095/biolreprod.109.077404)

Lin BC, Suzawa M, Blind RD, Tobias SC, Bulun SE, Scanlan TS \& Ingraham HA 2009 Stimulating the GPR30 estrogen receptor with a novel tamoxifen analogue activates SF-1 and promotes endometrial cell proliferation. Cancer Research 69 5415-5423. (doi:10.1158/0008-5472. CAN-08-1622)

Liu H, Luo LL, Qian YS, Fu YC, Sui XX, Geng YJ, Huang DN, Gao ST \& Zhang RL 2009 FOXO3a is involved in the apoptosis of naked oocytes and oocytes of primordial follicles from neonatal rat ovaries. Biochemical and Biophysical Research Communications 381 722-727. (doi:10.1016/j.bbrc.2009.02.138)

Lubahn DB, Moyer JS, Golding TS, Couse JF, Korach KS \& Smithies O 1993 Alteration of reproductive function but not prenatal sexual development after insertional disruption of the mouse estrogen receptor gene. PNAS 90 11162-11166. (doi:10.1073/pnas.90.23.11162)

Lydon JP, DeMayo FJ, Funk CR, Mani SK, Hughes AR, Montgomery CA Jr, Shyamala G, Conneely OM \& O'Malley BW 1995 Mice lacking progesterone receptor exhibit pleiotropic reproductive abnormalities. Genes and Development 9 2266-2278. (doi:10.1101/gad.9.18.2266)

Lydon JP, DeMayo FJ, Conneely OM \& O'Malley BW 1996 Reproductive phenotpes of the progesterone receptor null mutant mouse. Journal of Steroid Biochemistry and Molecular Biology 56 67-77. (doi:10.1016/ 0960-0760(95)00254-5)

Maggiolini M \& Picard D 2010 The unfolding stories of GPR30, a new membrane-bound estrogen receptor. Journal of Endocrinology 204 105-114. (doi:10.1677/JOE-09-0242)

Mazaud S, Guyot R, Guigon CJ, Coudouel N, Le Magueresse-Battistoni B \& Magre S 2005 Basal membrane remodeling during follicle histogenesis in the rat ovary: contribution of proteinases of the MMP and PA families. Developmental Biology 277 403-416. (doi:10.1016/j.ydbio.2004.10.001)

McClellan KA, Gosden R \& Taketo T 2003 Continuous loss of oocytes throughout meiotic prophase in the normal mouse ovary. Developmental Biology 258 334-348. (doi:10.1016/S0012-1606(03)00132-5)

McCright B, Gao X, Shen L, Lozier J, Lan Y, Maguire M, Herzlinger D, Weinmaster G, Jiang R \& Gridley T 2001 Defects in development of the kidney, heart and eye vasculature in mice homozygous for a hypomorphic Notch2 mutation. Development 128 491-502.

McGee EA \& Hsueh AJ 2000 Initial and cyclic recruitment of ovarian follicles. Endocrine Reviews 21 200-214. (doi:10.1210/er.21.2.200)

McMullen ML, Cho BN, Yates CJ \& Mayo KE 2001 Gonadal pathologies in transgenic mice expressing the rat inhibin alpha-subunit. Endocrinology 142 5005-5014. (doi:10.1210/en.142.11.5005)

Monk M \& McLaren A 1981 X-chromosome activity in foetal germ cells of the mouse. Journal of Embryology and Experimental Morphology 63 75-84.
Mulac-Jericevic B, Mullinax RA, DeMayo FJ, Lydon JP \& Conneely OM 2000 Subgroup of reproductive functions of progesterone mediated by progesterone receptor-B isoform. Science 289 1751-1754. (doi:10.1126/ science.289.5485.1751)

Mulac-Jericevic B, Lydon JP, DeMayo FJ \& Conneely OM 2003 Defective mammary gland morphogenesis in mice lacking the progesterone receptor B isoform. PNAS 100 9744-9749. (doi:10.1073/pnas. 1732707100)

Nandedkar T, Dharma S, Modi D \& Dsouza S 2007 Differential gene expression in transition of primordial to preantral follicles in mouse ovary. Society of Reproduction and Fertility Supplement 63 57-67.

Nilsson EE \& Skinner MK 2009 Progesterone regulation of primordial follicle assembly in bovine fetal ovaries. Molecular and Cellular Endocrinology 313 9-16. (doi:10.1016/j.mce.2009.09.004)

Nilsson EE, Stanfield J \& Skinner MK 2006 Interactions between progesterone and tumor necrosis factor-alpha in the regulation of primordial follicle assembly. Reproduction 132 877-886. (doi:10. 1530/REP-06-0045)

Nilsson EE, Schindler R, Savenkova MI \& Skinner MK 2011 Inhibitory actions of anti-Mullerian hormone (AMH) on ovarian primordial follicle assembly. PLOS ONE 6 e20087. (doi:10.1371/journal.pone. 0020087)

O'Shaughnessy PJ, Marsh P \& Dudley K 1994 Follicle-stimulating hormone receptor mRNA in the mouse ovary during post-natal development in the normal mouse and in the adult hypogonadal (hpg) mouse: structure of alternate transcripts. Molecular and Cellular Endocrinology 101 197-201. (doi:10.1016/0303-7207(94)90235-6)

Otto C, Fuchs I, Kauselmann G, Kern H, Zevnik B, Andreasen P, Schwarz G, Altmann H, Klewer M, Schoor M et al. 2009 GPR30 does not mediate estrogenic responses in reproductive organs in mice. Biology of Reproduction 80 34-41. (doi:10.1095/biolreprod.108.071175)

Paredes A, Garcia-Rudaz C, Kerr B, Tapia V, Dissen GA, Costa ME, Cornea A \& Ojeda SR 2005 Loss of synaptonemal complex protein-1, a synaptonemal complex protein, contributes to the initiation of follicular assembly in the developing rat ovary. Endocrinology 146 5267-5277. (doi:10.1210/en.2005-0965)

Parrott JA \& Skinner MK 1999 Kit-ligand/stem cell factor induces primordial follicle development and initiates folliculogenesis. Endocrinology $\mathbf{1 4 0}$ 4262-4271. (doi:10.1210/en.140.9.4262)

Pedram A, Razandi M \& Levin ER 2006 Nature of functional estrogen receptors at the plasma membrane. Molecular Endocrinology 20 1996-2009. (doi:10.1210/me.2005-0525)

Peluso JJ 2006 Multiplicity of progesterone's actions and receptors in the mammalian ovary. Biology of Reproduction 75 2-8. (doi:10.1095/ biolreprod.105.049924)

Pepling ME \& Spradling AC 1998 Female mouse germ cells form synchronously dividing cysts. Development 125 3323-3328.

Pepling ME \& Spradling AC 2001 The mouse ovary contains germ cell cysts that undergo programmed breakdown to form follicles. Developmental Biology 234 339-351. (doi:10.1006/dbio.2001.0269)

Pepling ME, Sundman EA, Patterson NL, Gephardt GW, Medico L Jr \& Wilson KI 2010 Differences in oocyte development and estradiol sensitivity among mouse strains. Reproduction 139 349-357. (doi:10. 1530/REP-09-0392)

Perez GI, Robles R, Knudson CM, Flaws JA, Korsmeyer SJ \& Tilly JL 1999 Prolongation of ovarian lifespan into advanced chronological age by Bax-deficiency. Nature Genetics 21 200-203. (doi:10.1038/5985)

Peters H 1969 The effect of radiation in early life of the morphology and reproductive function of the mouse ovary. In Advances in Reproductive Physiology, pp 149-185. Ed. A McLaren. Edinburgh: Logos Press Limited.

Pettersson K \& Gustafsson JA 2001 Role of estrogen receptor beta in estrogen action. Annual Review of Physiology 63 165-192. (doi:10. 1146/annurev.physiol.63.1.165)

Qiu J, Bosch MA, Tobias SC, Krust A, Graham SM, Murphy SJ, Korach KS, Chambon P, Scanlan TS, Ronnekleiv OK et al. 2006 A G-protein-coupled estrogen receptor is involved in hypothalamic control of energy homeostasis. Journal of Neuroscience 26 5649-5655. (doi:10.1523/ JNEUROSCI.0327-06.2006)

Rajah R, Glaser EM \& Hirshfield AN 1992 The changing architecture of the neonatal rat ovary during histogenesis. Developmental Dynamics 194 177-192. (doi:10.1002/aja.1001940303) 
Rajareddy S, Reddy P, Du C, Liu L, Jagarlamudi K, Tang W, Shen Y, Berthet C, Peng SL, Kaldis P et al. 2007 p27kip1 (cyclin-dependent kinase inhibitor 1B) controls ovarian development by suppressing follicle endowment and activation and promoting follicle atresia in mice. Molecular Endocrinology 21 2189-2202. (doi:10.1210/me.2007-0172)

Rajkovic A, Pangas SA, Ballow D, Suzumori N \& Matzuk MM 2004 NOBOX deficiency disrupts early folliculogenesis and oocyte-specific gene expression. Science 305 1157-1159. (doi:10.1126/science.1099755)

Ratts VS, Flaws JA, Klop R, Sorenson CM \& Tilly JL 1995 Ablation of bcl-2 gene expression decreases the number of oocytes and primordial follicles established in the postnatal female mouse gonad. Endocrinology 136 3665-3668. (doi:10.1210/en.136.8.3665)

Reddy P, Liu L, Adhikari D, Jagarlamudi K, Rajareddy S, Shen Y, Du C, Tang W, Hamalainen T, Peng SL et al. 2008 Oocyte-specific deletion of Pten causes premature activation of the primordial follicle pool. Science 319 611-613. (doi:10.1126/science.1152257)

Reith AD, Rottapel R, Giddens E, Brady C, Forrester L \& Bernstein A 1990 W mutant mice with mild or severe developmental defects contain distinct point mutations in the kinase domain of the c-kit receptor. Genes and Development 4 390-400. (doi:10.1101/gad.4.3.390)

Revankar CM, Cimino DF, Sklar LA, Arterburn JB \& Prossnitz ER 2005 A transmembrane intracellular estrogen receptor mediates rapid cell signaling. Science 307 1625-1630. (doi:10.1126/science.1106943)

Reynaud K, Cortvrindt R, Smitz J, Bernex F, Panthier JJ \& Driancourt MA 2001 Alterations in ovarian function of mice with reduced amounts of KIT receptor. Reproduction 121 229-237. (doi:10.1530/rep.0.1210229)

Robles R, Morita Y, Mann KK, Perez GI, Yang S, Matikainen T, Sherr DH \& Tilly JL 2000 The aryl hydrocarbon receptor, a basic helix-loop-helix transcription factor of the PAS gene family, is required for normal ovarian germ cell dynamics in the mouse. Endocrinology 141 450-453. (doi:10. 1210/en.141.1.450)

Rodrigues P, Limback D, McGinnis LK, Plancha CE \& Albertini DF 2009 Multiple mechanisms of germ cell loss in the perinatal mouse ovary. Reproduction 137 709-720. (doi:10.1530/REP-08-0203)

Roy SK \& Albee L 2000 Requirement for follicle-stimulating hormone action in the formation of primordial follicles during perinatal ovarian development in the hamster. Endocrinology 141 4449-4456. (doi:10. 1210/en.141.12.4449)

Roy AK, Lavrovsky Y, Song CS, Chen S, Jung MH, Velu NK, Bi BY \& Chatterjee B 1999 Regulation of androgen action. Vitamins and Hormones 55 309-352.

Saville B, Wormke M, Wang F, Nguyen T, Enmark E, Kuiper G, Gustafsson JA \& Safe S 2000 Ligand-, cell-, and estrogen receptor subtype (alpha/beta)dependent activation at GC-rich (Sp1) promoter elements. Journal of Biological Chemistry 275 5379-5387. (doi:10.1074/jbc.275.8.5379)

Schindler R, Nilsson E \& Skinner MK 2010 Induction of ovarian primordial follicle assembly by connective tissue growth factor CTGF. PLoS One $\mathbf{5}$ e12979.

Schmidt D, Ovitt CE, Anlag K, Fehsenfeld S, Gredsted L, Treier AC \& Treier M 2004 The murine winged-helix transcription factor Foxl2 is required for granulosa cell differentiation and ovary maintenance. Development 131 933-942.

Senger PL 2003 Pathways to Pregnancy and Parturition, Pullman, WA: Current Conceptions, Inc.

Soyal SM, Amleh A \& Dean J 2000 FIGalpha, a germ cell-specific transcription factor required for ovarian follicle formation. Development 127 4645-4654.

Spears N, Molinek MD, Robinson LL, Fulton N, Cameron H, Shimoda K, Telfer EE, Anderson RA \& Price DJ 2003 The role of neurotrophin receptors in female germ-cell survival in mouse and human. Development 130 5481-5491. (doi:10.1242/dev.00707)

Susiarjo M, Hassold TJ, Freeman E \& Hunt PA 2007 Bisphenol A exposure in utero disrupts early oogenesis in the mouse. PLoS Genetics 3 e5. (doi:10.1371/journal.pgen.0030005)

Suzuki A, Sugihara A, Uchida K, Sato T, Ohta Y, Katsu Y, Watanabe H \& Iguchi T 2002 Developmental effects of perinatal exposure to bisphenol-A and diiethylstilbestrol on reproductive organs in female mice. Reproductive Toxicology 16 107-116. (doi:10.1016/S0890-6238(02)00005-9)

Suzumori N, Yan C, Matzuk MM \& Rajkovic A 2002 Nobox is a homeoboxencoding gene preferentially expressed in primordial and growing oocytes. Mechanisms of Development 111 137-141. (doi:10.1016/ S0925-4773(01)00620-7)
Thomas P, Pang Y, Filardo EJ \& Dong J 2005 Identity of an estrogen membrane receptor coupled to a $\mathrm{G}$ protein in human breast cancer cells. Endocrinology 146 624-632. (doi:10.1210/en.2004-1064)

Trombly DJ, Woodruff TK \& Mayo KE 2008 Suppression of Notch signaling in the neonatal mouse ovary decreases primordial follicle formation. Endocrinology 150 1014-1024. (doi:10.1210/en.2008-0213)

Trombly DJ, Woodruff TK \& Mayo KE 2009 Roles for transforming growth factor beta superfamily proteins in early folliculogenesis. Seminars in Reproductive Medicine 27 14-23. (doi:10.1055/s-0028-1108006)

Uda $M$, Ottolenghi $C$, Crisponi L, Garcia JE, Deiana M, Kimber W, Forabosco A, Cao A, Schlessinger D \& Pilia G 2004 Foxl2 disruption causes mouse ovarian failure by pervasive blockage of follicle development. Human Molecular Genetics 13 1171-1181. (doi:10.1093/hmg/ddh124)

Vomachka AJ \& Greenwald GS 1979 The development of gonadotropin and steroid hormone patterns in male and female hamsters from birth to puberty. Endocrinology 105 960-966. (doi:10.1210/endo-105-4-960)

de Vries FA, de Boer E, van den Bosch $M$, Baarends WM, Ooms M, Yuan L, Liu JG, van Zeeland AA, Heyting C \& Pastink A 2005 Mouse Sycp1 functions in synaptonemal complex assembly, meiotic recombination, and XY body formation. Genes and Development 19 1376-1389. (doi:10.1101/gad.329705)

Wang J \& Roy SK 2004 Growth differentiation factor-9 and stem cell factor promote primordial follicle formation in the hamster: modulation by follicle-stimulating hormone. Biology of Reproduction 70 577-585. (doi:10.1095/biolreprod.103.023234)

Wang C \& Roy SK 2007 Development of primordial follicles in the hamster: role of estradiol-17beta. Endocrinology 148 1707-1716. (doi:10.1210/ en.2006-1193)

Wang C \& Roy SK 2010 Expression of E-cadherin and N-cadherin in perinatal hamster ovary: possible involvement in primordial follicle formation and regulation by follicle-stimulating hormone. Endocrinology 151 2319-2330. (doi:10.1210/en.2009-1489)

Wang C, Prossnitz ER \& Roy SK 2008 G protein-coupled receptor 30 expression is required for estrogen stimulation of primordial follicle formation in the hamster ovary. Endocrinology 149 4452-4461. (doi:10. 1210/en.2008-0441)

Wang N, Zhang P, Guo X, Zhou Z \& Sha J 2011 Hnrnpk, a protein differentially expressed in immature rat ovarian development, is required for normal primordial follicle assembly and development. Endocrinology 152 1024-1035. (doi:10.1210/en.2010-0797)

Xue Y, Gao X, Lindsell CE, Norton CR, Chang B, Hicks C, GendronMaguire M, Rand EB, Weinmaster G \& Gridley T 1999 Embryonic lethality and vascular defects in mice lacking the Notch ligand Jagged1. Human Molecular Genetics 8 723-730. (doi:10.1093/hmg/8.5.723)

Yan C, Wang P, DeMayo J, DeMayo FJ, Elvin JA, Carino C, Prasad SV, Skinner SS, Dunbar BS, Dube JL et al. 2001 Synergistic roles of bone morphogenetic protein 15 and growth differentiation factor 9 in ovarian function. Molecular Endocrinology 15 854-866. (doi:10.1210/me.15.6.854)

Yang MY \& Fortune JE 2008 The capacity of primordial follicles in fetal bovine ovaries to initiate growth in vitro develops during mid-gestation and is associated with meiotic arrest of oocytes. Biology of Reproduction 78 1153-1161. (doi:10.1095/biolreprod.107.066688)

Yoshida H, Takakura N, Kataoka H, Kunisada T, Okamura H \& Nishikawa SI 1997 Stepwise requirement of c-kit tyrosine kinase in mouse ovarian follicle development. Developmental Biology 184 122-137. (doi:10. 1006/dbio.1997.8503)

Yuan L, Liu JG, Hoja MR, Wilbertz J, Nordqvist K \& Hoog C 2002 Female germ cell aneuploidy and embryo death in mice lacking the meiosis-specific protein SCP3. Science 296 1115-1118. (doi:10.1126/science.1070594)

Zachos NC, Billiar RB, Albrecht ED \& Pepe GJ 2002 Developmental regulation of baboon fetal ovarian maturation by estrogen. Biology of Reproduction 67 1148-1156. (doi:10.1095/biolreprod67.4.1148)

Received 14 August 2011

First decision 12 September 2011

Revised manuscript received 18 October 2011

Accepted 7 November 2011 